\title{
Insulin receptor tyrosine kinase activity is reduced in monocytes from non-obese normoglycaemic insulin-resistant subjects
}

\author{
L. Frittitta, G. Grasso, M. E. Munguira, R. Vigneri, V. Trischitta \\ Cattedra di Endocrinologia e Patologia Costituzionale, Università di Catania, Catania, Italy
}

\begin{abstract}
Summary. Insulin sensitivity has been quantified by i.v. insulin tolerance test $(0.1 \mathrm{U} / \mathrm{kg}$ of body weight $)$ in 18 (11 male/7 female) non-obese (body mass index range 19 $25 \mathrm{~kg} / \mathrm{m}^{2}$ ) normoglycaemic subjects. We then compared the tyrosine kinase activity and internalization of insulin receptor in monocytes from the six most insulin-sensitive (group 1) and the six most insulin-resistant (group 3) subjects. Tyrosine kinase activity was measured on immunopurified receptors using ${ }^{32} \mathrm{P}-\mathrm{ATP}$ and poly-glutamic acid 4 : tyrosine 1 , sodium salt (poly-glu-tyr 4:1). Insulin internalization was studied by incubating cells with $1 \mathrm{nmol} /{ }^{125} \mathrm{I}$-insulin and measuring total cell-bound and intracellular ${ }^{125} \mathrm{I}$-insulin by an acid dissociation procedure. Basal (in the absence of insulin) receptor kinase activity was similar in both groups. Maximal (in the presence of $100 \mathrm{nmol} / \mathrm{l}$ insulin) kinase activity was $41 \%$ lower in group $3\left(13.8 \pm 3.6\right.$ fmoles ${ }^{32} \mathrm{P}-\mathrm{ATP}$ incorporated vs $23.3 \pm 4.0, p=0.1$ ). Delta increment of receptor kinase activ-
\end{abstract}

ity after insulin stimulation (calculated by subtracting basal from maximal activity) was significantly $(p<0.05)$ reduced in group $3(21.3 \pm 3.8$ vs $11.1 \pm 2.1)$ and significantly $(p<0.05)$ correlated to the in vivo insulin sensitivity. Both total cell-bound $(0.70 \pm 0.09 \%$ of total radioactivity added vs $0.83 \pm 0.15)$ and intracellular $(0.39 \pm 0.05 \text { vs } 0.44 \pm 0.09)^{225} \mathrm{I}-$ insulin were similar in the two groups. These data suggest that in non-obese, normoglycaemic subjects a defective insulin receptor tyrosine kinase activity may contribute to the development of insulin resistance. This raises the possibility that the reduced receptor kinase activity observed in Type 2 (non-insulin-dependent) diabetic patients may be independent from the diabetes and may in fact precede the appearance of the disease.

Key words: Insulin receptor, tyrosine kinase, internalization, insulin resistance, human monocytes.
The molecular mechanisms and the primary defects responsible for insulin resistance, a well-known characteristic of Type 2 (non-insulin-dependent) diabetes mellitus [1,2], are not completely understood. One possible molecular site of the defective insulin action is the insulin receptor. In Type 2 diabetic patients several studies have demonstrated that insulin receptor function may be defective as demonstrated by a reduced tyrosine kinase activity [3-7] or a reduced internalization [8-10] or both. However, whether these defects in insulin receptor function are primary or secondary to the metabolic alterations associated with Type 2 diabetes such as hyperglycaemia, obesity and hyperinsulinaemia, remains to be elucidated.

Recently it was demonstrated that approximately $25 \%$ of non-obese normoglycaemic subjects have a similar degree of insulin resistance as obese and Type 2 diabetic patients [1]. These subjects, therefore, represent an excellent natural model to verify whether or not the alterations of insulin receptor function precede the appearance of and are independent from the metabolic alterations associ- ated with Type 2 diabetes. We first quantified insulin sensitivity in 18 non-obese, normoglycaemic volunteers and then compared insulin receptor tyrosine kinase activity and internalization in monocytes from the six subjects who were most insulin-sensitive to that from the six who were most insulin resistant.

\section{Subjects, materials and methods}

Crystalline porcine insulin, Triton X-100, bacitracin, phenylmethylsulphonylfluoride (PMSF) and poly Glu-Tyr (4:1) were purchased from Sigma Chemical Co. (London, UK). ${ }^{125}{ }^{-}-\mathrm{A}_{14}$-insulin $(340-360 \mu \mathrm{Ci} / \mu \mathrm{g})$ was kindly provided by Dr. L. Benzi (Pisa, Italy). $\left[\gamma^{32} \mathrm{P}\right]$ ATP was obtained from Amersham LTD (London, UK). Nicodenz was purchased from Immuna (Pisa, Italy). 
Table 1. Insulin sensitivity, calculated from the rate of glucose disappearance after i. v. insulin injection ( $K_{\text {itt }}$ values), and clinical features of the non-obese normoglycaemic subjects studied

\begin{tabular}{|c|c|c|c|c|c|c|}
\hline \multirow[t]{2}{*}{ Subjects } & \multicolumn{2}{|l|}{$\mathrm{K}_{\mathrm{itt}}$} & \multirow[t]{2}{*}{ Sex } & \multirow{2}{*}{$\begin{array}{l}\text { Age } \\
\text { (years) }\end{array}$} & \multirow{2}{*}{$\begin{array}{l}\text { Body mass } \\
\text { index } \\
\left(\mathrm{kg} / \mathrm{m}^{2}\right)\end{array}$} & \multirow[t]{2}{*}{ Group } \\
\hline & $1^{\circ}$ & $2^{\circ}$ & & & & \\
\hline 1 & 6.5 & & $\mathrm{M}$ & 34 & 25 & 1 \\
\hline 2 & 6.2 & & $\mathrm{~F}$ & 38 & 20 & \\
\hline 3 & 6.0 & 6.0 & $\mathrm{~F}$ & 30 & 21 & \\
\hline 4 & 6.0 & & M & 27 & 23 & \\
\hline 5 & 5.2 & 4.9 & $\mathrm{M}$ & 35 & 22 & \\
\hline 6 & 5.1 & & $\mathrm{~F}$ & 29 & 24 & \\
\hline Mean \pm & 5.8 & & & 32 & 22 & \\
\hline SEM & 0.2 & & & 2 & 1 & \\
\hline 7 & 4.9 & & F & 27 & 22 & 2 \\
\hline 8 & 4.9 & & M & 26 & 21 & \\
\hline 9 & 4.8 & & $\mathrm{M}$ & 37 & 19 & \\
\hline 10 & 4.7 & & $\mathrm{~F}$ & 26 & 22 & \\
\hline 11 & 4.7 & & F & 32 & 21 & \\
\hline 12 & 4.6 & & M & 30 & 24 & \\
\hline Mean \pm & 4.8 & & & 30 & 21 & \\
\hline SEM & 0.1 & & & 2 & 1 & \\
\hline 13 & 4.4 & & M & 34 & 22 & 3 \\
\hline 14 & 4.4 & 4.4 & M & 33 & 22 & \\
\hline 15 & 4.2 & & $\mathrm{~F}$ & 32 & 22 & \\
\hline 16 & 4.1 & & M & 43 & 24 & \\
\hline 17 & 3.8 & & M & 32 & 23 & \\
\hline 18 & 3.5 & 3.8 & M & 24 & 23 & \\
\hline Mean \pm & 4.0 & & & 33 & 23 & \\
\hline SEM & 0.1 & & & 2 & 1 & \\
\hline
\end{tabular}

\section{Selection of insulin-sensitive and insulin-resistant subjects}

Eighteen healthy non-obese subjects from the staff of the Endocrinology Department of the University of Catania, were studied after giving their informed consent. The clinical characteristics of the group are shown in Table 1 . None of them had diabetes, according to the criteria of the National Diabetes Data Group [11]. All subjects were on a weight-maintaining diet $(50 \%$ carbohydrate, $30 \%$ lipid, $20 \%$ protein).

After an overnight fast, insulin sensitivity was assessed by i. v. insulin tolerance test (ITT), performed as previously described [12]: a single bolus of $0.1 \mathrm{IU} / \mathrm{kg}$ body weight of regular insulin was injected i.v. into an antecubital vein. Blood samples were collected 15 and 5 min before and 3, 6, 9, 12, and 15 min after insulin injection. Glucose was injected at 15 min to stop the fall in the plasma glucose. The constant rate for plasma glucose disappearance $\left(K_{i t}\right)$ was calculated according to the formula $0.693 / t_{1 / 2}$. The plasma glucose $t_{1 / 2}$ was calculated from the slope of least square analysis of the plasma glucose concentration from 3-15 min after i.v. insulin injection, when the plasma glucose concentration declined linearly. The results obtained with this test correlate highly with those obtained with euglycaemic hyperinsulinaemic clamp studies and are not influenced by counterregulatory hormones in the $3-15 \mathrm{~min}$ period of the study [12]. In order to verify the reproducibility of $K_{\text {itt }}$ values, a second ITT was carried out in four subjects within 1-3 weeks from the first test. In all four subjects the $\mathrm{K}_{\mathrm{itt}}$ value obtained with the second test was within $10 \%$ of the first value obtained (Table 1). Using the $K_{\text {itt }}$ values, subjects were subdivided in three groups (Table 1 ) ( $r$-values for $t / 2$ plasma glucose disappearance during min 3-15 after insulin injection were $0.984 \pm 0.001,0.990 \pm 0.01$ and $0.961 \pm$ 0.001 , mean \pm SEM in group 1,2 and 3 , respectively). The six most insulin-sensitive (group 1), and the six most insulin-resistant (group 3) subjects, volunteered to participate in further studies.
One insulin-sensitive subject and three insulin-resistant subjects were first degree relatives of Type 2 diabetic patients. In order to evaluate insulin sensitivity under more physiological conditions, plasma glucose and insulin levels were measured in subjects from group 1 and 3 after a standard mixed meal ( $450 \mathrm{kcal}, 50 \%$ carbohydrate, $30 \%$ lipid and $20 \%$ protein) given between 08.00 and 09.00 hours, following a 13-h fast. Plasma glucose and insulin levels were measured immediately before (time 0 ) and 30,60, 90 and 120 min after the beginning of the meal (subjects were asked to eat their meal in less than 15 min).

\section{In vitro studies}

Cell preparation: mononuclear cells were obtained from $150 \mathrm{ml}$ blood (withdrawn immediately before the meal profile test) by the use of Nicodenz according to the previously described procedure [10]. The percentage of monocytes was determined by non-specific esterase staining and ranged $80-93 \%$ of total mononuclear cell number with no difference between the two groups of subjects. Cell viability, at the end of the experiments, was greater than $93 \%$ as judged by the trypan blue exclusion technique.

Cell solubilization: monocytes were solubilized in $50 \mathrm{mmol} / \mathrm{l}$ Hepes buffer pH 7.6, containing $0.15 \mathrm{~mol} / \mathrm{l} \mathrm{NaCl}, 1 \%$ Triton $\mathrm{X}-100$, $5 \mathrm{mmol} / 1 \mathrm{EDTA}, 5 \mathrm{mmol} / 1 \mathrm{EGTA}, 20 \mathrm{mmol} / 1 \mathrm{sodium}$ pyrosphosphate, $1 \mathrm{mmol} / 1 \mathrm{PMSF}, 1 \mathrm{mmol} / 1$ sodium vanadate, $20 \mathrm{mmol} / 1$ sodium fluoride, $1 \mathrm{mg} / \mathrm{ml}$ bacitracin. Solubilized material was then centrifuged at $10,000 \times g$ in a Beckman microfuge and the supernatant used for both tyrosine kinase studies and measurement of the insulin receptor content by radioimmunoassay.

Tyrosine kinase studies: this assay was performed by a modification of the previously described procedure [13]. Briefly, 96-well microtitre polyvinylchloride plates (Falcon, Oxnard, Calif., USA) were coated with $50 \mu \mathrm{l}$ of anti-mouse $\operatorname{IgG}(10 \mu \mathrm{g} / \mathrm{ml}$ final concentrations, in $20 \mathrm{mmol} / 1 \mathrm{NaHCO}_{3} \mathrm{pH} 9.6$ ) and incubated overnight at $4{ }^{\circ} \mathrm{C}$. The wells were then washed three times with $50 \mathrm{mmol} / \mathrm{l}$ Hepes buffer, pH 7.6, containing $0.15 \mathrm{~mol} / \mathrm{l} \mathrm{NaCl}, 0.1 \%$ Triton $\mathrm{X}-100,0.1 \%$ Tween-20, and $0.1 \%$ bovine serum albumin (BSA), coated with $50 \mu$ of anti-human insulin receptor mouse monoclonal antibody 29 B4 (kindly provided by Dr. R. Roth, Palo Alto, Calif., USA), $10 \mu \mathrm{g} / \mathrm{ml}$ final concentration, incubated overnight at $4^{\circ} \mathrm{C}$ and finally washed again three times with $50 \mathrm{mmol} / \mathrm{l} \mathrm{Hepes} \mathrm{buffer.} \mathrm{Solubilized}$ cells ( $40 \mu \mathrm{l}, 0.7-1.0 / 10^{6}$ monocytes) were then added to the wells and incubated overnight at $4^{\circ} \mathrm{C}$. Wells were then washed three times with $50 \mathrm{mmol} / 1$ Hepes buffer and immunopurified insulin receptors pre-incubated for $30 \mathrm{~min}$ at $22^{\circ} \mathrm{C}$ in the presence or absence of $100 \mathrm{nmol} / 1$ insulin in $50 \mathrm{mmol} / 1$ Hepes buffer, $\mathrm{pH} 7.4$, containing $0.1 \%$ Triton $\mathrm{X}-100,2 \mathrm{mmol} / 1 \mathrm{MnCl}_{2}$ and $10 \mathrm{mmol} / \mathrm{L} \mathrm{MgCl}_{2}$. Next $10 \mu \mathrm{mol} / 1$ ATP, $\gamma_{-}{ }^{32} \mathrm{P}$ ATP $(2 \mu \mathrm{Ci} /$ well $)$ and the synthetic substrate poly-Glu: Tyr 4:1 (1 mg/ml final concentration) were added, the incubation continued for a further $60 \mathrm{~min}$ at $22^{\circ} \mathrm{C}$ and the radioactivity incorporated into the exogenous substrate then measured. Nonspecific incorporation was determined in parallel wells which were not coated with the anti-insulin receptor monoclonal antibody. Results were normalised for insulin binding values measured in parallel wells where immunopurified insulin receptors were incubated at $22^{\circ} \mathrm{C}$ with $1 \mathrm{nmol} /{ }^{125} \mathrm{I}-\mathrm{A}_{14}$ insulin (in the absence or presence of $10 \mu \mathrm{mol} / \mathrm{l}$ native insulin) in $50 \mathrm{mmol} / 1$ Hepes binding buffer ( $\mathrm{pH} 7.8,1 \% \mathrm{BSA})$. After $2 \mathrm{~h}$ wells were washed five times with chilled $50 \mathrm{mmol} / 1$ Hepes binding buffer and then cut and the bound radioactivity counted. This method has a detection limit of $0.2 \mathrm{fem}-$ tomoles of ${ }^{32} \mathbf{P}$ incorporated in the exogenous substrate. Inter-assay coefficient of variation was $14 \pm 3 \%$ and $10 \pm 5 \%$ for basal and $100 \mathrm{nmol} / \mathrm{l}$ insulin stimulated tyrosine kinase activity, respectively. Inter-assay coefficient of variation was $21 \pm 2 \%$ and $14 \pm 3 \%$ for basal and $100 \mathrm{nmol} / 1$, respectively.

Radioimmunoassay of insulin receptor: total cellular insulin receptor content was measured in solubilized cells by a sensitive and specific radioimmunoassay as previously described [10]. 
Table 2. Tyrosine kinase activity of insulin receptors immunopurified from monocytes of the 12 subjects studied

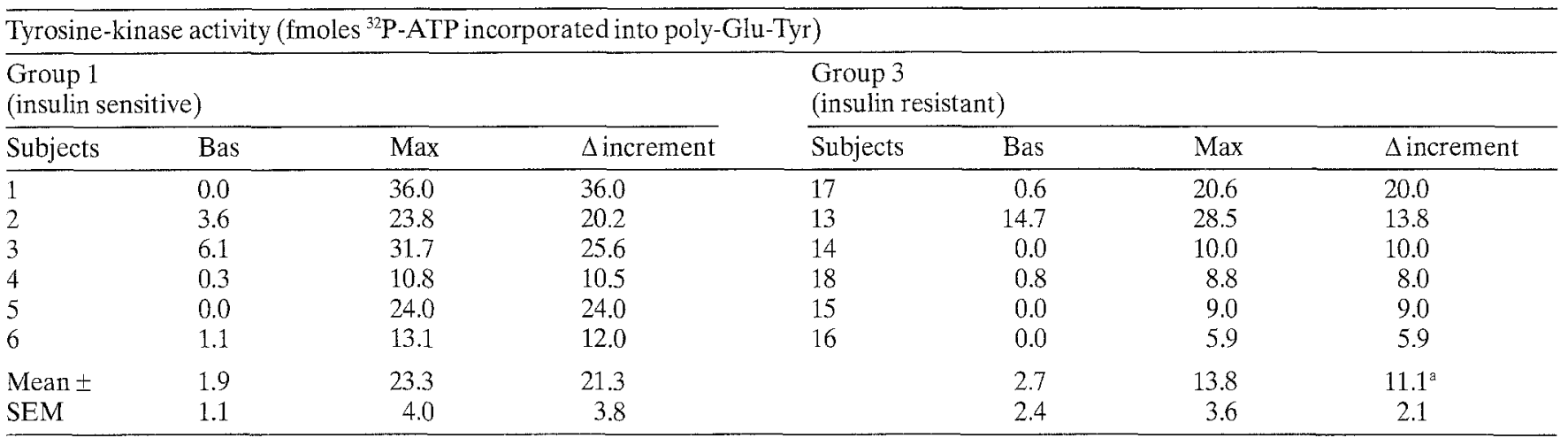

${ }^{a} p<0.05$ vs group 1. Subjects are numbered according to Table 1. Bas, Basal value (in the absence of insulin); Max, maximal value (in the presence of $100 \mathrm{nmol} / \mathrm{l}$ insulin); $\Delta$ increment, maximal value

Insulin internalization studies: monocytes $\left(0.7-1.0 \times 10^{6}\right.$ cells $)$ were incubated with $1 \mathrm{nmo} / 1 /{ }^{125} \mathrm{I}-\mathrm{A}^{14}$ insulin (in the absence or the presence of $10 \mu \mathrm{mol} / 1$ native insulin) in Hepes binding buffer at $37^{\circ} \mathrm{C}$ for $30 \mathrm{~min}$. Total cell-bound and internalized insulin was then measured by an acid dissociation procedure as previously described [9].

\section{Statistical analysis}

Unpaired Student's $t$-test was used to compare mean values. A twoway ANOVA test was used to compare plasma glucose and insulin profiles after meal ingestion. Linear regression analysis was used to determine numerical correlation between variables.

\section{Results}

In non-obese normoglycaemic subjects the range of insulin sensitivity may vary [1]. This is confirmed in our study as the non-obese normoglycaemic subjects selected as insulin resistant by ITT (group 3) were also resistant to insulin at the meal profile test. In fact, compared to subjects from group 1 , subjects from group 3 , whilst having a similar glucose profile had a significantly $(p<0.01$ by twoway ANOVA) higher plasma insulin levels after meal ingestion (data not shown).

\section{In vitro studies on monocyte insulin receptors of subjects from group 1 and 3}

Insulin receptor tyrosine kinase activity. Basal (in the absence of insulin) tyrosine kinase activity was similar in both groups (Table 2). Maximal (in the presence of $100 \mathrm{nmol} / \mathrm{l}$ insulin) tyrosine kinase activity was, although $41 \%$ lower, not significantly different $(p=0.1)$ in subjects from group 3 (Table 2). The delta increment of tyrosine kinase activity after insulin stimulation, calculated by subtracting basal activity from maximal activity (in the presence of $100 \mathrm{nmol} / 1$ insulin), was significantly $(p<0.05)$ reduced in insulin receptors from insulin-resistant (group 3) subjects $(11.1 \pm 2.1)$ compared to receptors from insulin-sensitive (group 1) subjects (21.3 \pm 3.8 ) (Table 2). minus basal value; fmoles, femtomoles. Data are normalised for insulin receptor binding activity

To exclude the influence of day to day variation in monocyte preparation and receptor immunopurification, one subject from group 1 and one subject from group 3 were always studied in parallel on the same day. In all six instances the delta increment of tyrosine kinase activity after insulin stimulation was lower in subjects from group 3, with the average ratio of group 3: group 1 being $0.54 \pm 0.06(p<0.01)$. When looking at the individual data, the tyrosine kinase activity delta increment was significantly correlated ( $r=0.66, p=0.02)$ to the $\mathrm{K}_{\text {itt }}$ value (Fig. 1), but not to the peak plasma insulin level after meal ingestion $(r=0.2)$.

Insulin receptor content. The insulin receptor content of mononuclear cells, was not different between group 1 $\left(2.20 \pm 0.34 \mathrm{ng} / 10^{6}\right.$ cells) and group $3(2.69 \pm 0.19)$.

Insulin internalization studies. Both total cell-bound and non-acid-extractable (intracellular) ${ }^{125}$ I-insulin was similar in mononuclear cells from the two groups studied. In group 1 and 3 cell-bound ${ }^{125} \mathrm{I}$-insulin was $0.70 \pm 0.09$ vs

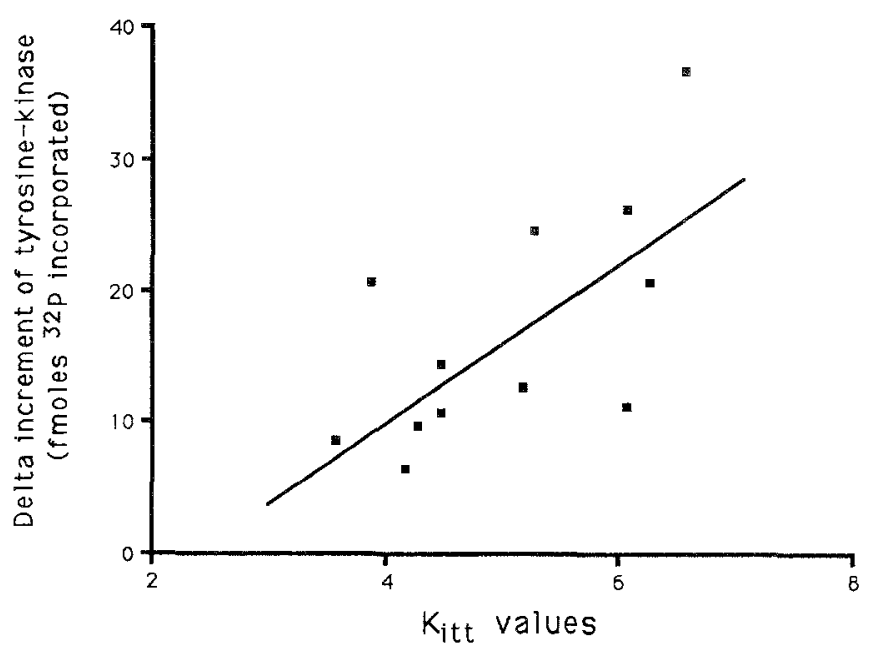

Fig. 1. Correlation between the delta increment of insulin receptor tyrosine kinase activity after in vitro insulin stimulation and in vivo insulin sensitivity, as calculated by the rate of glucose disappearance after $i$. v insulin injection ( $\mathrm{K}_{\mathrm{itt}}$ values), in the 12 subjects studied 
$0.83 \pm 0.15 \%$ and non-acid-extractable ${ }^{125} \mathrm{I}$-insulin was $0.39 \pm 0.05$ vs $0.44 \pm 0.09 \%$ of total radioactivity added per $10^{6}$ monocytes, respectively. Also the percentage of bound insulin that was internalized was similar in both groups ( $57 \pm 5$ and $55 \pm 5 \%$ in group 1 and 3 , respectively).

\section{Discussion}

Defective tyrosine kinase activity [3-7] and internalization [8-10] of the insulin receptor have been reported in Type 2 diabetic patients, but it is not known whether or not these altered receptor functions are consequences of the metabolic alterations associated with diabetes.

In this study we observed a reduced insulin stimulation of receptor tyrosine kinase activity and a normal receptor internalization in monocytes from non-obese, normoglycaemic, insulin-resistant subjects. Furthermore in these subjects the in vitro insulin effect on receptor tyrosine kinase activity was significantly correlated to the in vivo insulin effect on glucose disposal, as assessed by ITT.

Although monocytes mirror typical insulin target cells with respect to many insulin receptor functions $[14,15]$ including stimulation of glucose transport [16], these cells are not a major target for insulin action and therefore caution should be used in extrapolating our finding to typical insulin target tissues such as muscle and adipose tissue. However, in a recent preliminary study a defective tyrosine kinase activity of muscle insulin receptor has been reported in normoglycaemic insulin-resistant first degree relatives of Type 2 diabetic patients [17]. Thus, in normoglycaemic insulin-resistant subjects a defective receptor tyrosine kinase activity may be a generalized phenomenon present in several tissues and may contribute to the induction of insulin resistance.

By showing that a reduced receptor tyrosine kinase activity may be present in insulin-resistant subjects in the absence of any significant clinical and metabolic alterations, our data suggest that this defect is independent from Type 2 diabetes and may, in fact, be an early step in the development of insulin resistance. In contrast to the reduced insulin receptor kinase activity, insulin internalization is normal in insulin-resistant normoglycaemic subjects indicating that the defective insulin internalization observed in Type 2 diabetic patients [8-10] is specifically related to diabetes itself.

In a previous study [15], we found that insulin receptor tyrosine kinase activity was not reduced in monocytes from six hyperinsulinaemic obese patients when compared to eight non-obese control subjects, a finding that may appear to contrast with the present observation. Many reasons may explain this apparent discrepancy. First, insulin sensitivity was not evaluated in the control subjects of the previous study and, based on our present data, some of them may have been insulin resistant. Secondly, different factors may contribute to insulin resistance and the mechanism involved in the insulin resistance of some obese patients may not necessarily be the same as in non-obese subjects. Thirdly, a different and more sensitive tyrosine kinase assay on immunopurified receptors was used in the present study, allowing a more specific evaluation of the insulin receptor function in respect to the wheat germ purified receptor preparations used in the previous study.

The cause of the reduced receptor tyrosine kinase activity in non-obese normoglycaemic insulin-resistant subjects is not known. It has been recently postulated [18] that up to $1 \%$ of the general population may be affected by mutations of the insulin receptor gene. Therefore, although a much higher percentage of insulin receptor gene mutations may be expected in insulin-resistant subjects, it is unlikely that the defective receptor kinase activity is due entirely to receptor gene mutations. An acquired defect of the receptor protein function, due to environmental modification, is also a possible cause of the altered receptor kinase in insulin-resistant non-obese normoglycaemic subjects. For instance, an elevated insulin concentration has been shown to deteriorate insulin receptor function in vitro $[19,20]$. A similar mechanism could explain the defective receptor tyrosine kinase activity in insulin-resistant subjects. However, in the insulin-resistant subjects we studied, this mechanism is unlikely because plasma insulin levels after meal ingestion, although significantly higher than those of insulin-sensitive subjects, were in the physiological range and cannot be considered hyperinsulinaemic. This is also confirmed by the lack of receptor down-regulation in monocytes of insulin-resistant subjects when receptor content was measured by both radioimmunoassay and insulin binding studies. Moreover, no correlation was observed between fasting or postprandial plasma insulin levels and receptor kinase activity.

In conclusion, a reduced insulin receptor tyrosine $\mathrm{ki}$ nase activity may contribute significantly to the induction of insulin resistance in non-obese normoglycaemic subjects. These data also suggest that the defective receptor kinase activity observed in Type 2 diabetic patients may be independent from their diabetes and may, instead, represent an early step in the development of human insulin resistance.

\section{References}

1. Reaven GM (1988) Banting Lecture: role of insulin resistance in human disease. Diabetes 37: 1595-1607

2. DeFronzo RA, Bonadonna RC, Ferrannini E (1992) Pathogenesis of NIDDM. A balanced overview. Diabetes Care 15: $318-368$

3. Caro JR, Ittop O, Pories WJ et al. (1986) Studies on the mechanism of insulin-resistance in the liver from humans with noninsulin-dependent diabetes. J Clin Invest 78: 249-258

4. Freidenberger GR, Henry RR, Klein HH, Reichart DR, Olefsky JM (1987) Decreased kinase activity of insulin receptors from adipocytes of non-insulin-dependent diabetic subjects. J Clin Invest 79: $240-250$

5. Caro JF, Sinha MK, Raju SM et al. (1987) Insulin receptor kinase in human skeletal muscle from obese subjects with and without noninsulin dependent diabetes. J Clin Invest 79: 1330-1337

6. Arner P, Pollare T, Lithell H, Livingstone JN (1987) Defective insulin receptor tyrosine-kinase in human skeletal muscle in obesity and type 2 (non-insulin-dependent) diabetes mellitus. Diabetologia 30: 437-440

7. Comi R, Grunberger C, Gorden P (1987) Relationship of insulin binding and insulin-stimulated tyrosine-kinase activity is altered in type II diabetes. J Clin Invest 79: 453-462 
8. Jochen AL, Berhanu P, Olefsky JM (1986) Insulin internalization and degradation in adipocytes from normal and type II diabetes subjects. J Clin Endocrinol Metab 62: 268-272

9. Trischitta V, Gullo D, Squatrito S, Pezzino V, Goldfine ID, Vigneri R (1986) Insulin internalization into monocytes is decreased in patients with type II diabetes mellitus. J Clin Endocrinol Metab 62: 522-529

10. Trischitta V, Brunetti A, Chiavetta A, Benzi L, Papa L, Vigneri R (1989) Defects in insulin-receptor internalization and processing in monocytes of obese subjects and obese NIDDM patients. Diabetes. 38: 1579-1584

11. National Diabetes Data Group (1979) Classification and diagnosis of diabetes mellitus and other categories of glucose intolerance. Diabetes 28: 1039-1057

12. Bonora E, Moghetti P, Zancanaro C et al. (1989) Estimates of in vivo insulin action in man: comparison of insulin tolerance tests with euglycemic and hyperglycemic glucose clamp studies. J Clin Endocrinol Metab 68: 374-378

13. Steele-Perkins G, Roth RA (1990) Insulin-mimetic anti-insulin receptor monoclonal antibodies stimulate receptor kinase activity in intact cells. J Biol Chem 265: 9458-9463

14. Grunberger G, Zick Y, Gorden P (1984) Defect in phosphorylation of insulin receptors in cells from an insulin-resistant patients with normal insulin binding. Science 223: 932-934

15. Trischitta V, Giorgino F, Frittitta L, Scalisi R, Vigneri R (1993) Relationship between insulin receptor tyrosine-kinase activity and internalization in monocytes of NIDDM patients. Metabolism 42: 882-887
16. Daneman D, Zinman B, Elliot ME, Bilan PS, Klip A (1992) Insulin-stimulated glucose transport in circulating mononuclear cells from nondiabetic and IDDM subjects. Diabetes 41:227-234

17. Handberg A, Vaag A, Vintent J, Beck-Nielsen H (1992) Defect insulin receptor kinase activation in skeletal muscle in young non-obese first degree relatives of patients with NIDDM. Diabetes 41 [Suppl 1]: 63A (Abstract)

18. Taylor SI, Cama A, Accili D et al. (1992) Mutations in the insulin receptor gene. Endocrine Rev 13: 566-595

19. Arsenis G, Livingstone $\mathbf{J}$ (1986) Alterations in the tyrosine kinase activity of the insulin receptor produced by in vitro hyperinsulinemia. J Biol Chem 261: 147-153

20. Williams JF, Olefsky JM (1990) Defective insulin receptor function in down-regulated HEPG2 cells. Endocrinology 127: $1706-1717$

Received: 25 March 1993

and in revised form: 10 June 1993
Dr. V. Trischitta
Endocrinologia
Ospedale Garibaldi
USL 34
Piazza S. M. Gesù
I-95123 Catania
Italy 